\title{
Stages Of The Formation And Implementation Of Social Policy
}

\section{${ }^{1}$ Khoshimov Pazliddin Zukhorovich, ${ }^{2}$ Abdullaeva Shakhnoza Erkinovna}

${ }^{1} \mathrm{PhD}$ in Economics, Professor, National University of Uzbekistan named after Mirzo Ulugbek, Tashkent, Uzbekistan.

${ }^{2}$ Scientific researcher, Tashkent State University of Oriental Studies, Tashkent, Uzbekistan.

Article History: Received:11 January 2021; Accepted: 27 February 2021; Published online: 5 April 2021

\begin{abstract}
The article looks at the concept of the socio-economic analysis of scientific sources carried out by scientists of four main historical stages of the formation and development of state social policy in the countries of Western Europe, which makes research topic relevant.

The scientific article gives scientific definitions to such categories as "social sphere", "social policy" by various scholars and authors. In addition, the article groups social protection programs, summarizes and comprehensively, analyzes the theoretical and scientific approaches to improving their effectiveness.

Having done an extensive analysis of the research materials, the author makes a conclusion about the urgency strengthening measures for social protection of the population in order to avoid further economic recession.
\end{abstract}

Keywords: Socio-economic analysis, human civilization, social policy, human rights, human society, social orientation, social contradictions, "Social Insurance Fund", "State Social Fund", minimum standard of living, the system of social guarantees.

Based on the socio-economic analysis of scientific sources carried out by scientists, four main historical stages of the formation and development of state social policy in the countries of Western Europe can be identified: ${ }^{1}$

Stage 1. II century. BC e. - XV century. n. e. - the emergence of objective prerequisites for the formation of social policy as a special type of state activity.

This stage is characterized by the emergence of social policy and its development in the subsequent centuries of the existence of human civilization on the European continent. Such great ancient philosophers as Plato and Aristotle made a great contribution to the development of social problems in terms of its influence on the development of social policy. Well-known thinkers of the past in their works addressed the issues of the structure of society and the social sphere, problems of the relationship between man and society, citizen and state, human rights and freedoms, etc. During this historical period, social policy evolved to a certain level of development and was a complex and diverse process, including almost all aspects of society, the selforganization of people in their social life. The beginning of the emergence of a social orientation in the activities of the state was carried out at the level of communities, cities, poles. The state power proceeded from the fact that the family, community, clan, etc. should deal with social issues.

Stage 2. XVI century - mid XIX century - the allocation and gradual formation of social policy as a relatively independent direction of state activity. During this historical period, social policy is formed as an integral part of the internal policy of the state and is carried out by its estate-representative bodies. They were state structures, whose competence included the duties of coordination and interaction of social interests of different strata of society, the resolution of social contradictions and conflicts. The measures taken by the state authorities were of an unsystematic and selective nature and concerned mainly the lower strata of society, who had no means of subsistence. Solving the problems of the poor and pauperism was the main task of social policy in this historical period [4]. In solving social issues, the state gave priority to the church, receiving in return spiritual support for the inviolability of power.

With the civilizational development of human society, new philosophical and theoretical approaches and concepts of the social purpose and social functions of the state were developed. The complication of social problems gave rise to the growth of contradictions and increased conflict in society. New problems of public life could not be resolved by the old methods of state management of the social sphere, which caused an increase in discontent among the population.

Stage 3. Mid-19th century - early 20th century - institutionalization of state social policy. The beginning of the formation of state social policy was laid by the introduction into scientific circulation in 1853

\footnotetext{
1 Юдин А.В. Исторические предпосылки и этапы формирования государственной социальной политики. // Вестник екатерининского института. 2015, № 1. - С. 149-150.
} 
by the German professor of the University of Munich VG Riehl of the term "social policy". And even the absence of the word "state" in the concept implied its actual participation in the practice of its implementation. This predetermined the essence of further theoretical development of the problem of determining the place and role of the state in the formation and implementation of social policy. At the end of the XIX century. the development of the problem of legislative regulation of state social policy begins, social institutions are formed that are involved in the implementation of social policy. Such well-known thinkers as W. Sombart, A. Wagner, G. Schmoler, and a number of others made a significant contribution to the study of the directions of social policy, methods of solving social problems. For example, in Germany, Chancellor Bismarck is creating a special state structure that calculates and pays social compensation and benefits for disability as a result of work injuries, disability and old age. The financing of these processes under the control of the state is carried out by the "Social Insurance Fund", which was established at the expense of workers, employees and employers. The process of forming the state German social security system begins.

Stage 4. The middle of the 20th century - to the present - the development and improvement of state social policy and the increase of its role and significance in the development of society.

At the beginning of the 20th century, the social policy of the state is being improved, overcoming its fragmentation and lack of system.

In the theoretical development of the foundations of state social policy at this stage, a significant role was played by the report of the famous English economist W. Beveridge, published in 1940, which highlights the creation of a system of state social security. For the first time, the idea of the advisability of social assistance to citizens who have lost the ability to self-sufficiency, in the form of payment of pensions and benefits by the "State Social Fund". ${ }^{2}$ A significant new milestone in the development of social policy in the pre-war period was the adoption of the Convention and the recommendations of the International Labor Organization, which had a significant impact on the social development of Western European countries. In the course of the development of the social security system, the role of the state has changed significantly. At the expense of tax collections and the state budget, the state has undertaken obligations to pay unemployment benefits, social old-age pensions, payment for medical services, social assistance payments, etc. The modern social policy of the most developed states is currently aimed at the formation of a new sociality, which involves the promotion of the social function of the state among the main ones. This, in turn, means the transformation of a person from a means of solving any problems into a goal of social development, and determining as a priority of state social policy the fullest possible provision of the rights and freedoms of citizens, the creation of decent social conditions for their existence.

Over the past 15-20 years, the following trends in the social policy of developed countries can be distinguished:

- expenditures on social policy in European countries have actually become equal: in southern European countries they have increased, in northern European ones they have stabilized optimally;

- family income protection programs are in place: expenses for housing and health insurance are reimbursed (Austria, Ireland, Luxembourg, France); reimbursement of housing costs, healthcare services, payment for the stay of children in preschool institutions (Finland, Germany, Portugal); reimbursement of housing costs and the cost of household items for those who cannot provide themselves for personal or social reasons (Spain, Sweden);

- a certain minimum standard of living is guaranteed for people with disabilities and people who have completely lost their ability to work (almost all European countries);

- social benefits for able-bodied, but no income citizens are not paid in Greece and Portugal; in Spain and Italy are paid only in certain regions from the local budget; Modestly paid in France and Great Britain; the largest allowance in comparison with other countries is paid in Denmark and the Netherlands;

- financial support for elderly and sick citizens, social payments for children and women for pregnancy and childbirth are carried out in all European countries, only the amount of these payments is variable;

- social assistance to single-parent families: in Greece, only a single mother receives such benefits; in Spain and Portugal, the benefit is paid only in certain regions; $+50 \%$ of a single parent's income to his / her salary until the child turns 3; in Denmark and the Netherlands this benefit exceeds $60 \%$ of the parent's salary; in other countries - much less. ${ }^{3}$

The main problems and urgent unsolved problems of social policy in modern developed countries at the beginning of the XXI century. became: the demographic crisis and the aging of the population, immigration and migration, the social consequences of structural changes in the economy and modernization of the economy, the

\footnotetext{
${ }^{2}$ https://ru.qwe.wiki/wiki/Beveridge_Report

3 Тезадова Д. А. Социальная политика в современных государствах: основное содержание, направления и модели. // Человек, сообщество, управление. 2015. Том 16. №3. - С. 99.
} 
creation of new forms of family and an increase in the number of single people, an increase in spending on social needs.

Also, disputes about the "breakingpoint" (turning point) in the taxation system remain unresolved: at what point an increase in tax rates on citizens' income will lead not to replenishment of the budget, but to the possibility of reducing the system of social payments to the population, and the reverse process - when low taxes will not be able to provide high level of social services for citizens of developed countries.

The basis of the social policy of the state of Uzbekistan at the stage of transition to the market were:

1. Freedom of economic activity as the basis for improving the well-being of the people.

2. Increasing labor activity as a condition for ensuring one's own well-being and family well-being, overcoming dependency in relation to the state.

3. The system of social guarantees - legislatively enshrined forms of minimum provision of the population at the expense of public consumption funds.

4. Targeted social protection of the population - the concentration of state support for not really needy segments of the population.

5. Regulation of income.

6. Promotion of employment of citizens;

7. Improvement of the demographic situation in the republic.

In the "Uzbek model," the state as the main reformer acts as the guarantor of social well-being, social peace and stability. The measures of social support for the population were diverse, but the main one was first subsidies for the prices of industrial goods, and then the allocation of resources for targeted social support. If earlier social support was massive in nature and consisted of the introduction of subsidized prices for food products sold to the population by the state, and this was covered by growing transfers, then later subsidized prices remained only for a limited range of consumer goods and for utilities that were used by the entire population.

This situation is explained by the introduction of market principles into the social sphere, when the social self-protection of able-bodied citizens becomes the most important market principle.

As the reforms deepened, the scope of the market law of distribution expanded, the essence of which is that the material goods and services created by the aggregate labor of society are distributed in accordance with the size of the efficiency of using the resources that each economic entity has. This law excludes dependency, and therefore the consumerist approach to economic resources. As this law is in effect, social protection changes its address, it aims to support precisely those strata of society that, due to their objective situation, with all their will, cannot provide themselves with consumer goods even in minimal amounts.

The reorientation of measures of social protection of the population is determined not by the law of market distribution, but by the humanistic principle of assistance to needy members of society from other members of society. This principle is implemented through the social activities of the state.

In the domestic scientific literature, it is customary to distinguish two stages of the implementation of strong social protection.

The first stage - from 1991 to 1994 - is characterized by the following priorities:

- support for household income in the context of price liberalization and high

inflation;

- protecting the national consumer market, which was still heavily dependent on imports of consumer goods;

- support for the poor who were unable to adapt to the new economic conditions.

The scope of the second stage is usually determined from the end of 1994 to the present. The criterion for distinguishing this stage is the gradual transition from the system of universal social protection to the creation of a mechanism of reliable social guarantees and support for the most vulnerable segments of the population. An equalizing system of social support for all strata of the population was consistently replaced by a differential approach to various social strata and groups. The so-called targeted social protection system began to be implemented in the republic - a system most widespread in the world and supported by the international community.

The most important characteristic features of this system in Uzbekistan are:

- priority spending of budgetary funds for the payment of the legally established minimum wages, pensions, benefits for socially vulnerable segments of the population, provision of free social services to certain categories of citizens; - creation of organizational and legislative conditions for the formation of the population's propensity to accumulate and invest income in various insurance funds; 
- an effective system of social and economic protection of employees by ensuring timely payments and
regular

As the reforms in the economy deepen and production grows, the entire system of social assistance is improving, its resources are growing.

Thanks to the transition to a targeted system of social assistance in the republic, it was possible to prevent an excessively sharp stratification of society into rich and poor. In world practice, it is believed that the difference in incomes of the $10 \%$ richest and $10 \%$ of the poorest in the optimal variant should not exceed a tenfold level.

In general, it should be noted that the complex of social policy measures actually implemented in Uzbekistan allows us to say that we have created an effective system of social management. Therefore, as one of the characteristics of the Uzbek model of a socially oriented market economy, one should single out the increased macroeconomic functional role of social management.

When considering the modern model of social policy in Uzbekistan, it is necessary to study the process of formation and development of social policy during the years of independence.

At the first stage of the transition period, from approximately the second half of 1991 to July 1994, against the background of soft monetary and budgetary policies, Uzbekistan pursued a liberal policy in the area of income generation and employment of the population.

In practice, this was ensured by the following measures:

In the field of production:

- maintaining a high level of employment;

- carrying out privatization and denationalization of property, respecting the interests of labor collectives;

- preservation of previously established guarantees in the field of labor relations; entrepreneurship.

- creation of appropriate conditions for the development of small business and private

\section{In the area of income distribution and redistribution:}

- the establishment of minimum wages, pensions, benefits, scholarships;

- indexation of household incomes in connection with the growth of inflation;

- redistribution of part of income in favor of low-income citizens.

\section{In the sphere of consumption:}

- protection of the domestic consumer market;

- increased production of consumer goods;

- creation of conditions for free exchange of goods;

- avoiding a sharp decline in consumption of basic food products;

- curbing the decline in the level of consumption of education and health services.

In the social protection system:

- ensuring the targeted nature of social protection of the population;

- the abandonment of numerous, significantly providing social benefits and the introduction of benefits aimed at the family;

- gradual abandonment of incentives and state support for high birth rates;

- attraction for social protection of the population, along with state financial sources, funds from sponsorship and other charitable organizations;

- rejection of expensive and bureaucratic schemes for identifying low-income families and transition to simpler and cheaper schemes for distributing state aid through local communities (mahallas).

Thus, the first stage of reforms from the point of view of income policy was characterized by the following main features:

1. Weak control over the population's monetary income.

2. A significant share of consumer subsidies in the total income of the population.

3. Formation of new sources of in-kind income of the population through the expansion of personal plots of citizens.

4. The slowdown in the growth of the level of official unemployment, due to the "softness" of the policy of releasing employees from unprofitable industries and the insufficient effectiveness of the adopted Law "On Bankruptcy".

All this made it possible to somewhat maintain the level of real disposable income of the population, mitigate its "losses" from price liberalization and prevent a shock of rising unemployment.

During the second stage of market reforms, in 1994-1996, when more severe monetary and budgetary policies were applied, the following changes took place in income policy:

1) the number and size of wage indexations has sharply decreased due to price increases. If in 1993 wages were indexed 7 times, then in 1994 - 5 times, in 1995 and 1996 - twice; 
2) indexation began to apply only to the budgetary sphere, and the wages of employees of economic entities were made dependent on the growth of production volumes $(0.7 \%$ growth of the wage fund for each percent with an increase in production volumes) or on the decision of a special commission on monetary politics;

3 ) consumer subsidies were reduced to a minimum and left only for certain types of housing and communal services;

4) the share of social transfers in the income of the population has significantly decreased.

Consequently, along with other measures of macroeconomic stabilization, this made it possible to reduce the inflation rate, to strengthen the market behavior of the population in the field of forming their own incomes.

In 1991-1995, the share of income received in the form of wages (from 57 percent to 44.2 percent) and other receipts from the financial system (from 3.3 percent to 1.1 percent) decreased in the structure of monetary incomes of the population. Over the same period, income from various types of entrepreneurial activity increased (from 2.4 percent in 1993 to 13.4 percent in 1995), as well as revenue from the sale of agricultural products (from 9.7 percent in 1991 to 19.2 percent). percent in 1995). ${ }^{4}$

Учитывая сложность осуществляемого реформирования на нынешнем его этапе в нашей республике определены социальные приоритеты, нацеленные на эффективное использование ограниченных финансовых ресурсов на стратегически важных направлениях, определяющих долгосрочные перспективы социальной политики.

The meaning of the economic and social reforms being carried out in Uzbekistan is to create conditions under which every citizen of the republic, regardless of nationality, religion and beliefs, would have the opportunity to reveal himself as a person, show his abilities, make his life better, worthy, spiritually richer ...

The guiding principle of Uzbekistan's own path of renewal and progress is pursuing a strong social policy. Providing reliable social guarantees and social protection measures for the population is a priority at all stages of market transformation and permeates other areas of the entire vast process of renewing our society.

Over the years of independence, a new mechanism for social protection of the population has been created in Uzbekistan, taking into account the real economic situation, available resources and opportunities.

Each stage of reforming society and the economy has developed its own concepts of social policy.

In the initial period of transition to the market, proactive social protection of the entire population was applied. Then the system of consumer subsidies and various forms of protection of the consumer market from the leakage of basic manufactured goods outside the country were widely used. Thanks to this, our republic managed to maintain social stability.

At the same time, such social protection measures contributed to the ingraining of extravagance and dependent psychology. Therefore, with the deepening of reforms and the development of market relations, significant adjustments were made to the priorities of the current social policy: an emphasis was placed on providing assistance to families in need, on the development and implementation of a mechanism for targeted social protection of the population. The social support system was aimed at eliminating egalitarian and dependent psychology. A distinctive feature of the new social protection system is a differentiated approach to different segments of the population.

The implementation of such a social policy is associated with the stabilization and sustainable development of production, the strengthening of the national currency, the intensification of investment activities and the course to support small business and private entrepreneurship. For social support of those in need, along with state sources, funds from labor collectives, public and charitable organizations and foundations have begun to be widely attracted. The formation of a powerful motivational mechanism, capable of providing the most complete activation of the forces and abilities of people, also played a role.

The cornerstone of social policy in Uzbekistan is family support. Taking into account the peculiarities of the national mentality and lifestyle of the population, it was applied and received wide support to identify the most needy families and provide them with assistance through the mahalla committees. This approach has centuriesold roots in our population and ensures the most targeted distribution of funds intended to support socially vulnerable citizens.

Special attention in our country is paid to reducing poverty and strengthening state support for vulnerable groups of the population. During the transition period, the latter also included people who did not belong to their wound - many of those who belonged to groups with an average level of income. Therefore, differentiated measures of social assistance are deeply studied and worked out, primarily for those who, due to the current circumstances, are most susceptible to poverty: disabled people, orphans, lonely elderly people. Social protection is acquiring an even more pronounced targeting, targeted orientation.

It is known that at the beginning of the transition period, price liberalization and denationalization of enterprises led to high inflation and an increase in the number of unemployed or part-time workers. This required the strengthening of his social support from the state.

\footnotetext{
${ }^{4}$ Данные Министерства экономики Республики Узбекистан.
} 
It should be noted that at that time, stimulating aggregate demand was one of the main factors in overcoming the economic downturn and overcoming the economic crisis. From this point of view, it was important to maintain the income of the population and preserve existing jobs. On the other hand, already in the pre-reform period, there was excessive employment in many sectors of the economy. This state of affairs was due to the institutional features of the planned economy, as well as the low technological level of production, the use of ineffective and low-productivity equipment and increased the labor intensity of the products, leading to their rise in price.

At the first stage of reforms, price liberalization led to high inflation rates, which negatively affected the living standards of the population. To mitigate this impact, the government of our republic was forced to index the current income of the population, especially those employed in budgetary sectors and having fixed incomes, at the expense of social transfers. However, due to the fact that this was to a large extent inflation in demand, the indexation of incomes caused its further increase and opposed measures to reduce it.

The reduction in budgetary financial resources and high inflation negatively affected, first of all, the real incomes of workers in budgetary sectors - education, health care, culture, government bodies. The salary at that time fell here below the level that allows retaining qualified personnel. This has led to the drain of the last of the most important areas of the economy that form human capital. There is a danger of a drop in the achieved level of development of industries working on the country's potential in the medium and long term. But the recent coordinated state measures have begun to noticeably improve the state of affairs in this direction.

It should be noted that even in the pre-reform period in our republic an irrational structure of nutrition was formed with a bias towards excessive consumption of carbohydrate products in place of protein foods and fats. In terms of consumption of meat and dairy products, Uzbekistan occupied one of the last places in the former Soviet Union. All this had a negative impact on the health of the population, on the incidence rates. The rapid rise in the cost of basic food products caused by price liberalization could exacerbate these trends; it was necessary to take measures of state protection of the level of consumption of vital products by the population.

A strong social policy is the guarantor of the protection and well-being of the population, the driving force behind the development of the republic. This principle in a market economy is one of the main directions of the policy of the leadership of Uzbekistan. Since the day of gaining independence, targeted measures have been taken in our country to improve the level and quality of life of the population.

A striking evidence of this is the annual announcement of the year in a specific social direction and the adoption of a corresponding state program with specific and comprehensive measures.

Social policy in Uzbekistan at all stages of market reforms includes a fairly wide range of issues, including the regulation of incomes of the population, employment and the formation of new labor relations, social protection and support of certain categories and groups of the population, the development of health care, physical culture and sports, education.

In the republic, in recent years, the focus has been on issues of further reforming and improving the education system. Annual spending on education in Uzbekistan is about 10-12 percent of GDP, which is almost 2 times higher than the corresponding UNESCO recommendations (6-7 percent) in terms of investments in education required to ensure sustainable development of the state.

The basis of the state social policy at the stage of transition to the market is:

- freedom of economic activity as the basis for improving the well-being of the people;

- increasing labor activity as a condition for ensuring their own well-being and the well-being of the family;

- targeted social protection of the population, the concentration of state support on the really needy segments of the population.

The main directions of the state social policy of Uzbekistan during the transition of the economy to market relations are:

- regulation of household income;

- social protection of the population and provision of social guarantees;

- solving employment problems;

- liquidation of environmentally harmful industries;

- reorganization of financing of health care, education, culture;

- improvement of the demographic situation in the republic.

Among the most important areas of social policy, labor problems occupy a special place. The role of labor as the basis of the life of society determines the need to develop and implement state policy in solving related problems in cooperation with trade unions and employers (entrepreneurs), as it follows from the principle of tripartism.

The main directions of state labor policy include:

- creation of economic and social conditions for strengthening the motives and incentives for highly productive work;

- creation of a system for regulating the rates and salaries of employees, regardless of the form of ownership; 
- development of state programs for increasing productivity and efficiency of labor based on the rational use of labor, material, technical and natural resources; - improvement of labor legislation, expansion of state guarantees, benefits and compensations in the field of labor and its payment;

- development of social partnership of the state with trade unions and other organizations of workers, entrepreneurs (employers) in solving labor issues and remuneration, resolving collective labor disputes (conflicts);

- development and implementation of the state policy of employment of the population;

- forecasting the development of population, the formation of the labor potential of society, taking into account demographic and socio-economic factors

Social protection concept. Social protection of the population in Uzbekistan

The transition to a market economy has caused an urgent need to introduce the concept of "social protection of the population." Social protection of the population is a system of direct targeted guarantees of the state to the population, providing normal living conditions.

In other words, the social protection system should be built on the basis of solving the problems of ensuring real socio-economic efficiency, and not from narrow considerations of the effectiveness of the market system. At the same time, social protection every time turns out to be objectively determined, on the one hand, by the system of economic relations in which it functions, and on the other, by the requirements of the current state of the world economy and the human community as a whole.

In a modern economy, which should be an "economy for a person", an effective system of social protection is needed - one that allows using the labor potential of each person regardless of his socio-economic status, regardless of which socio-economic group he belongs to. This is how you can achieve effective use of human potential and what is called "confidence in the future." If such protection is not ensured, then it becomes impossible or at least significantly hinders the use of qualified labor, which should have the ability to retrain, master new things, and create. In other words, the existence of an effective social protection system is an integral feature of a modern economy based on the labor of a skilled worker.

\section{References}

1. Bobkov V.O. О социальном измерении нового этапа развития // Экономист. - 2013. - № 5. - С. 61-72.

2. Bobrova S.G. Реформа бюджетных учреждений в рамках социально_ориентированной бюджетной политики // Современные исследования социальных проблем. - 2012. - № 10. - С. $17-19$.

3. Tezadova D. А. Социальная политика в современных государствах: основное содержание, направления и модели. // Человек, сообщество, управление. 2015. Том 16. №3. - С. 99.

4. Kaev А.О. О стратегии интегрированной модернизации экономики России до 2025 года // Вопросы экономики. - 2012. -№ 4. - С. 97-116.

5. Kelarev V.V. Экономические факторы и некоторые особенности современной социальной политики государства.

6. Voronina A.S., Gorina M.S. Особенности социальной политики в социальном государстве. // Вестник экономики, права и социологии, 2012, № 3.

7. Кара-Мурза С.Г. Что такое социальное государство? - URL: http://mailto:info@ contrtv.ru

8. Nikoloeva A.A. Факторный анализ признаков социальной активности современного студенчества как показатель конфликтологической компетентности // Актуальные вопросы кадрового и образовательного менеджмента: сб. научных статей. М., 2015.

9. Oleynikova E.G. Модели социальной политики государства: проблемы теории и прак-тики // Общество: политика, экономика, право. 2016. № (3).

10. Savchenco I.A. Модель социальной политики современной России // Инновационная наука. 2016. № 3-4 (15).

11. Yudin A.V. Исторические предпосылкии этапы формирования государственной социальной политики. // Вестник екатерининского института. 2015, № 1.

12. Smirnov S.N., Sidorina T.Yu. Социальная политика: учебник. М.: Издательский дом ГУ ВШЭ, 2004. C. 122.

13. Konchugov A.V. Социальная политика как явление общественной жизни. М.: Власть, 2011. №9. C.97. 
14. Lipset S. Некоторые социальные предпосылки демократии: Экономическое развитие и политическая легитимность / пер. с англ. // Концепция модернизации в зарубежной социально политической теории, 1950-1960 гг.: Сб. переводов РАН. ИНИОН. - М., 2012. - С. 35-86.

15. Bobkov V. O социальном измерении нового этапа развития // Экономист. - 2013. - № 5. - C. 6172 . 